\title{
PENGARUH UMUR PANEN TERHADAP KUALITAS MINUMAN SARI RUMPUT GANDUM (WHEATGRASS) VARIETAS GURI-3 AGRITAN
}

Effect of Harvest Age on Quality of Wheatgrass Juice Drink (Variety Guri-3 Agritan).

\author{
Muhammad Syafi' ${ }^{1)}$, Hapsari Titi Palupi ${ }^{2)}$ \\ ${ }^{1)}$ Mahasiswa Ilmu dan Teknologi Pangan, Fakultas Pertanian, Universitas Yudharta Pasuruan \\ ${ }^{2)}$ Dosen Ilmu dan Teknologi Pangan, Fakultas Pertanian, Universitas Yudharta Pasuruan \\ E mail : syafi.hr@gmail.com
}

\begin{abstract}
ABSTRAK
Penelitian ini dilakukan untuk mencari tahu pengaruh umur panen terhadap kualitas mutu minuman sari rumput gandum (wheatgrass) varietas guri-3 agritan. Metode yang digunakan yaitu Rancangan Acak Kelompok (RAK) faktor tunggal dengan 4 perlakuan yaitu umur 11 hari, 12 hari, 13 hari dan 14 hari dan 3 kali ulangan. Analisis data menggunakan analisis ragam ANOVA dengan selang kepercayaan $1 \%$ dan 5\%, apabila ditemukan pengaruh terhadap salah satu variabel maka dilanjutkan dengan uji BNT. Pengamatan yang dilakukan meliputi Total Kadar Gula, Derajat Keasaman ( $\mathrm{pH}$ ), rendemen dan uji organoleptik meliputi rasa, aroma dan warna. Hasil penelitian menunjukkan Total Kadar Gula sebesar 3,83-6,83\%, pH 6,40 - 6,53, rendemen 80,86\% - 82,10\%. Terdapat pengaruh umur panen terhadap kandungan total kadar gula minuman sari rumput gandum. Kombinasi perlakuan terbaik terdapat pada U12H (umur panen 12 hari) dengan total kadar gula sebesar 4,33\%, $\mathrm{pH} 6,53$ dan rendemen 82,10\%. Hasil uji organoleptik pada 20 panelis menunjukkan bahwa rasa dan aroma tidak diterima oleh panelis sedangkan warna masih dapat diterima.

Kata kunci: minuman, rumput gandum, guri-3 agritan
\end{abstract}

\section{ABSTRACT}

This research was conducted to find out the influence of harvest age on quality of wheat grass juice varieties of guri-3 agritan. The method used is Single Randomized Block Design (RBD) with 4 treatment factors ie age 11 days, 12 days, 13 days and 14 days and 3 repetitions. Data analysis using ANOVA variance analysis with 1\% and 5\% confidence interval, if found influence on one variable then continued with BNT test. Observations made include Total Sugar Level, Degree of acidity ( $\mathrm{pH}$ ), yield and organoleptic test include flavor, aroma and color. The result showed that total sugar content was 3,83-6,83\%, pH 6,40 - 6,53, yield 80,86\% - 82,10\%. There is influence of harvest age to total content of grain juice. The best treatment combination was found in U12H (12 days harvest age) with total sugar content 4,33\%, pH 6,53 and yield 82,10\%. The results of organoleptic tests on 20 panelists show that flavor and aroma are not accepted by the panelists while the color is still acceptable.

Keywords: drink, wheatgrass, guri-3 agritan

\section{PENDAHULUAN}

Selama ini pemanfaatan gandum di Indonesia dominan digunakan untuk memproduksi tepung terigu sebagai

bahan baku pembuatan roti, mie, kue dan lain sebagainya. Namun seiring dengan 
perkembangan pola konsumsi masyarakat di Indonesia, beberapa masyarakat mulai memanfaatkan rumput gandum (wheatgrass) sebagai minuman yang kemudian dikenal sebagai minuman sari rumput gandum (wheatgrass).

Sari rumput gandum merupakan minuman kaya nutrisi yang terbuat dari tanaman gandum (Triticum aestivum L.) yang masih muda usianya. Secara umum minuman sari rumput gandum (wheatgrass) merupakan minuman yang terbuat dari ekstrak tanaman gandum berumur muda yang masih dalam tahap pertumbuhan dan berbentuk rumput. Tetapi jika rumput gandum dipanen pada umur yang terlalu muda, maka sari rumput gandum (wheatgrass) yang dihasilkan akan menjadi terlalu sedikit karena pertumbuhan rumput gandum (wheatgrass) belum sempurna dan maksimal. Sedangkan jika terlambat dan dipanen pada umur yang terlalu tua, maka rasa dari sari rumput gandum (wheatgrass) akan menjadi sangat pahit. Hal ini bisa disebabkan karena perbedaan umur panen sehingga terjadi perubahan kandungan kimia di dalamnya, khususnya karbohidrat. Karena menurut Winarno (2004), karbohidrat memiliki peranan penting dalam menentukan karakteristik bahan makanan, misalnya rasa, warna, tekstur dan lain-lain.

Agrawal et al (2015) telah melaporkan bahwa terjadi perbedaan kandungan mineral dan aktivitas antioksidan yang signifikan dalam jus rumput gandum dengan umur panen dan ketinggian rumput yang berbeda. Dari hasil penelitian tersebut bisa disimpulkan bahwa terdapat perbedaan kandungan kimia pada rumput gandum berdasarkan umur panen. Sehingga umur panen dapat dijadikan sebagai salah satu faktor yang dapat mempengaruhi kualitas mutu dalam pembuatan minuman sari rumput gandum (wheatgrass).

Tanaman gandum merupakan tanaman subtropis. Menurut Wigmore (1985), suhu optimal yang diperlukan untuk bisa menumbuhkan rumput gandum (wheatgrass) sehingga mendapatkan minuman sari rumput gandum dengan kandungan nutrisi yang maksimal yaitu $65-75^{\circ} \mathrm{F}(18.33-23.89$ ${ }^{\circ}$ C). Hal ini sesuai dengan penelitian yang telah dilakukan oleh Ashish, et al. (2012), dimana suhu pertumbuhan yang baik untuk menghasilkan rumput gandum (wheatgrass) dengan ketinggian 7 inch $(17-18 \mathrm{~cm})$ dalam waktu 11 hari yaitu dikisaran suhu $18-26^{\circ} \mathrm{C}$. Suhu tersebut sangat sulit sekali didapatkan di negara 
Indonesia karena Indonesia bukan negara dengan iklim subtropis. Sehingga daerah di Indonesia yang paling memungkinkan untuk bisa menumbuhkan rumput gandum (wheatgrass) secara optimal yaitu daerah dataran tinggi dengan kisaran suhu optimum $\leq 26^{\circ} \mathrm{C}$.

Pada tahun 2014 Badan Penelitian dan Pengembangan Pertanian (Balitbangtan) bersama Konsorsium Gandum Nasional yang melibatkan beberapa institusi telah berhasil merakit varietas unggul gandum toleran suhu tinggi yang diberi nama Guri-3 Agritan dan Guri-4. Penggunaan istilah Guri mengandung makna Gandum untuk Rakyat Indonesia. (Rahayu, 2016).

Varietas gandum ini tergolong varietas baru sehingga penulis mencoba menggunakan varietas ini sebagai obyek penelitian dalam pembuatan minuman sari rumput gandum (wheatgrass) untuk mengetahui pengaruh umur panen terhadap kualitas mutu minuman.

\section{METODE PENELITIAN}

Bahan yang digunakan adalah rumput gandum (wheatgrass) varietas Guri-3 Agritan yang dibeli di toko Jogja Wheatgrass.

Alat yang digunakan adalah hand refractometer, termometer ruangan, humidity meter, termometer bahan pangan, lux meter, timbangan digital, freezer, hand juicer dan hand sprayer.

Percobaan dilakukan dengan menggunakan Rancangan Acak Kelompok (RAK) yang terdiri dari satu faktor dengan kelompok panen umur 11 hari, 12 hari, 13 hari dan 14 hari. Masingmasing diulang 3 kali. Selanjutnya akan dilakukan analisis Total Kadar Gula, derajat keasaman $(\mathrm{pH})$, rendemen dan uji organoleptik.

\section{Metode Pengumpulan Data}

Metode pengumpulan data yang digunakan pada penelitian ini adalah dengan melakukan pengamatan pada kimiawi dan organoleptik. kimiawi meliputi. Karakteristik organoleptik yang meliputi penilaian terhadap warna, aroma, rasa, dan tekstur. Data yang meliputi karakteristik kimiawi diperoleh dari laboratorium, sedangkan data karakteristik organoleptik diperoleh dari pengisian skor kesukaan oleh panelis 20 orang bukan ahli. Skala nilai kesukaan mulai 1 (sangat tidak suka) sampai 5 (sangat suka).

\section{Metode Analisa Data}

Analisis data dilakukan secara ANOVA (Analysis of Variance) dengan 
selang kepercayaan 5\% dan $1 \%$. Apabila ditemukan pengaruh nyata terhadap salah satu variabel maka dilanjutkan dengan uji beda nyata terkecil (BNT). Sedangkan untuk uji organoleptik menggunakan uji friedman dan perlakuan terbaik menggunakan indeks efektifitas (Susrini,2003).

\section{HASIL DAN PEMBAHASAN}

\section{Analisa Total Kadar Gula}

Total kadar gula merupakan jumlah total kandungan gula yang terdapat di dalam bahan pangan baik gula pereduksi maupun non pereduksi. Tujuan dilakukannya analisis total kadar gula pada pembuatan minuman sari rumput gandum (wheatgrass) yaitu untuk mengukur jumlah semua jenis gula pada sampel. Rerata total kadar gula pada pembuatan minuman sari rumput gandum juga dapat dilihat pada gambar 1.

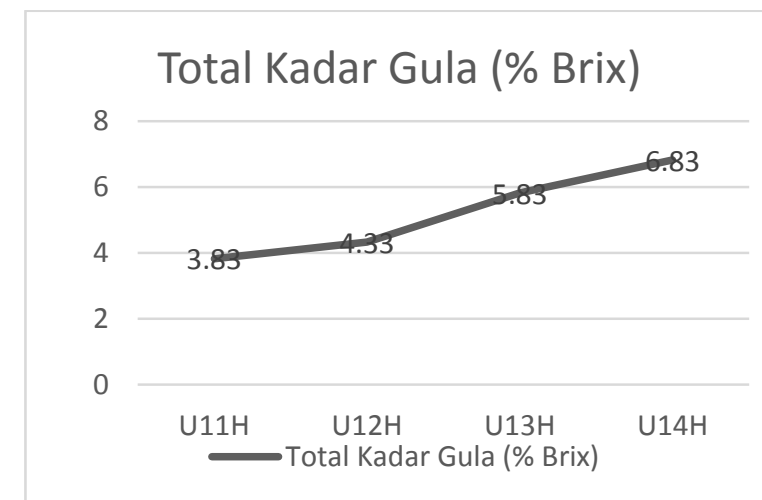

Gambar 1 Rerata Total Kadar Gula (\%Brix)
Berdasarkan hasil analisis total kadar gula pada pembuatan minuman sari rumput gandum (wheatgrass) diperoleh rata-rata total kadar gula 3,83\% sampai $6,83 \%$ brix. Hasil analisa sidik ragam menunjukkan bahwa terdapat pengaruh sangat nyata dalam perlakuan umur panen rumput gandum terhadap rata-rata kadar gula minuman sari gandum. Dari gambar diatas menunjukan semakin lama umur panen rumput gandum, maka kadar gula minuman sari rumput gandum semakin meningkat. Perlakuan umur panen 14 hari memberikan rerata total kadar gula tertinggi yaitu $6,83 \%$ brix.

Pada pembuatan minuman sari rumput tidak ditambahkan gula tambahan di dalamnya sehingga hasil tersebut merupakan kadar gula total asli (pereduksi dan non pereduksi) yang terdapat pada minuman sari rumput gandum (wheatgrass). Semakin lama umur panen, semakin terjadi peningkatan pada kadar karbohidrat. Dalam proses fotosintesis, tumbuhan menghasilkan zat makanan berupa karbohidrat $\left(\mathrm{C}_{6} \mathrm{H}_{12} \mathrm{O}_{6}\right)$ dan oksigen $\left(\mathrm{O}_{2}\right)$ dengan memanfaatkan pigmen klorofil yang ada di dalam kloroplas untuk menyerap cahaya. Cadangan makanan tersebut disimpam di daun dan bagian tanaman yang lain. 
Menurut Hariyani dkk. (2015) umur pemanenan merupakan aspek yang erat hubungannya dengan fase pertumbuhan tanaman yang mencerminkan tingkat kematangan fisiologis tanaman dan mempunyai relevansi yang kuat dengan produksi dan kandungan yang ada dalam tanaman.

\section{Analisis Derajat Keasaman (pH)}

$\mathrm{pH}$ adalah derajat keasaman yang digunakan untuk menyatakan tingkat keasaman atau kebasaan yang dimiliki oleh suatu larutan. Pengukuran derajat keasaman minuman sari rumput gandum (wheatgrass) dilakukan dengan menggunakan alat $\mathrm{pH}$ meter. Rerata nilai $\mathrm{pH}$ pada pembuatan minuman sari rumput gandum (wheatgrass) dapat dilihat pada gambar 2

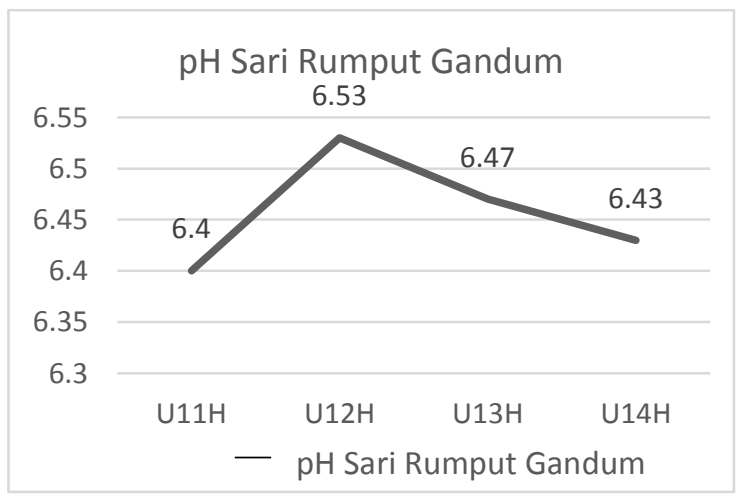

Gambar 2 Rerata pH sari rumput gandum

Berdasarkan hasil analisis $\mathrm{pH}$ (derajat keasaman) pada pembuatan minuman sari rumput gandum (wheatgrass) diperoleh rata-rata nilai $\mathrm{pH}$ antara 6,4 sampai 6,53. Minuman dengan $\mathrm{pH}<7$ tergolong minuman bersifat asam, sedangkan $\mathrm{pH}>7$ bersifat basa. Air murni bersifat netral pada $\mathrm{pH} 7$ dengan suhu $25^{\circ} \mathrm{C}$, bukan asam maupun basa (Kieran, 2006). Pada pembuatan minuman sari rumput gandum (wheatgrass) diperoleh nilai $\mathrm{pH}$ 6,40 6,53 dimana range tersebut masuk ke dalam minuman sedikit asam.

Analisis ragam tidak menunjukkan adanya pengaruh perbedaan umur panen terhadap derajat keasaman $(\mathrm{pH})$ minuman sari rumput gandum $\left(\mathrm{F}_{\text {hitung }}(0,2727)<\right.$ $\left.\mathrm{F}_{\text {tabel }(0,05)}\right)$.

\section{Rendemen}

Pengujian rendemen dilakukan untuk mengetahui perbandingan berat awal rumput gandum (wheatgrass) dengan berat akhirnya saat menjadi produk minuman. Sehingga dapat diketahui kehilangan beratnya ketika mengalami proses pengolahan. Rendemen didapat dengan cara menimbangkan hasil berat akhir yang dihasilkan dari proses dibandingkan dengan berat awal sebelum mengalami proses. Adapun rumus perhitungan rendemen minuman sari rumput gandum adalah sebagai berikut: 
Rendemen $(\%)=$ $\frac{\text { Jumlah Minuman yang dihasilkan }}{\text { Jumlah bahan sebelum diolah }} \times 100 \%$

Rerata nilai rendemen pada pembuatan minuman sari rumput gandum (wheatgrass) dapat dilihat pada gambar 3

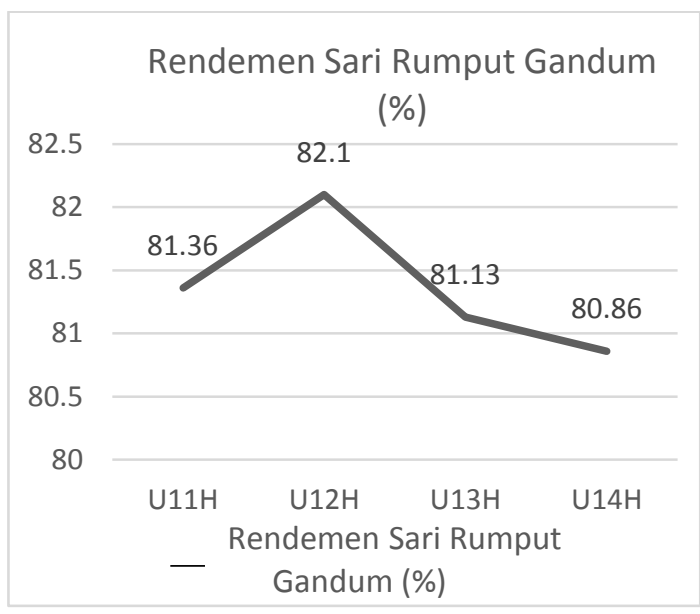

Gambar 3. Rerata Rendemen sari rumput gandum

Berdasarkan hasil analisis rendemen pada pembuatan minuman sari rumput gandum (wheatgrass) diperoleh rata-rata nilai rendemen $80,86 \%$ $82,10 \%$. Prosentase tertinggi didapatkan pada perlakuan $\mathrm{U} 12 \mathrm{H}$ (umur panen 12 hari) dengan nilai rata-rata $82,10 \%$. Sedangkan prosentase rendemen terendah didapatkan pada perlakuan U14H (umur panen 14 hari) dengan nilai 80,86\%. Penurunan nilai pada rendemen minuman disebabkan karena kadar air pada perlakuan U14H (umur panen 14 hari) lebih sedikit dari perlakuan yang lain.
Semakin lama umur panen wheatgrass, semakin sedikit kadar airnya. Analisis ragam tidak menunjukkan adanya pengaruh perbedaan umur panen terhadap rendemen minuman sari rumput gandum ( $\left.F_{\text {hitung }}(1,3409)<\mathrm{F}_{\text {tabel }(0,05)}\right)$.

\section{Analisa Organoleptik}

Uji organoleptik merupakan hasil reaksi fisikologis berupa tanggapan atau kesan mutu oleh sekelompok orang yang disebut dengan panelis (Muthmainnah, 2014). Uji organoleptik mempunyai peranan dan makna yang sangat besar dalam penilaian mutu produk pangan, baik sebagai bahan pangan hasil pertanian, bahan mentah industri maupun produk pangan olahan. Meskipun dengan uji-uji fisik dan kimia serta uji gizi dapat menunjukkan suatu produk pangan bermutu tinggi, namun akan tidak ada artinya jika produk pangan itu tidak dapat dimakan karena tidak enak atau sifat organoleptik lainnya tidak membangkitkan selera. Jadi bagi komoditas pangan pengujian organoleptik merupakan suatu keharusan (Soekarto, 1990).

Uji organoleptik dilakukan pada 4 sampel produk minuman sari rumput gandum pada 20 panelis agak ahli. Uji organoleptik dimaksudkan untuk menilai 
daya terima konsumen dan tingkat kesukaan terhadap produk. 4 sampel produk yang diujikan adalah minuman sari rumput gandum dengan umur panen 11 hari (U11H), 12 hari (U12H), 13 hari (U13H) dan 14 hari (U14H). Uji organoleptik meliputi uji rasa, aroma dan warna.

\section{Rasa}

Uji organoleptik rasa merupakan bentuk penilaian terhadap suatu produk dengan melibatkan indera perasa. Rasa merupakan salah satu atribut mutu yang paling penting dalam menentukan tingkat penerimaan terhadap suatu produk makanan. Berdasarkan hasil uji tingkat kesukaan panelis terhadap rasa minuman sari rumput gandum (wheatgrass), didapatkan nilai rerata tertinggi sebesar 2,75 (tidak suka) pada perlakuan $\mathrm{U} 14 \mathrm{H}$ (umur panen 14 hari) dan rerata terendah sebesar 2,05 (tidak suka) pada perlakuan

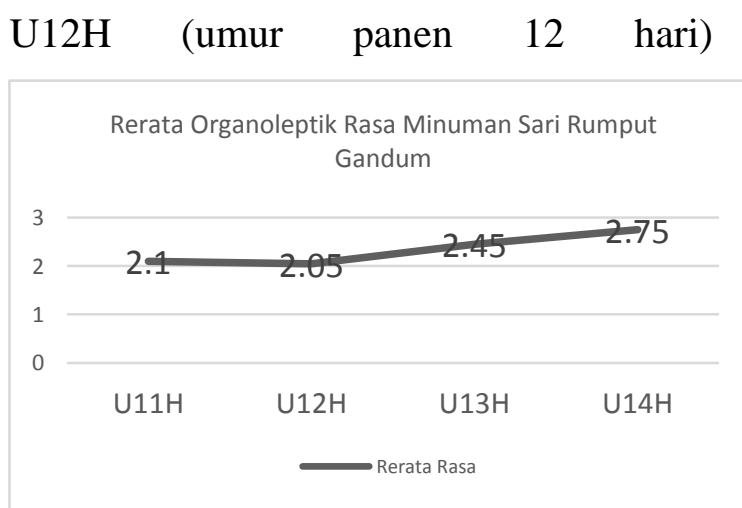

Gambar 4 Diagram Rerata Rasa Minuman Sari Rumput Gandum
Pada gambar 4. di atas menunjukkan bahwa semakin lama umur panen pada pembuatan minuman sari rumput gandum (wheatgrass), semakin tinggi nilai tingkat kesukaan panelis. Hanya terdapat sedikit perbedaan pada perlakuan U11H dan U12H. Dimana nilai rerata rasa pada perlakukan $\mathrm{U} 12 \mathrm{H}$ sedikit lebih rendah 0,05 dengan $\mathrm{U} 11 \mathrm{H}$.

Terdapat juga korelasi antara hasil uji organoleptik rasa pada minuman sari rumput gandum (wheatgrass) dengan uji total kadar gula. Dimana perlakuan umur panen 14 hari (U14H) yang memiliki nilai rerata rasa tertinggi $(2,75)$ juga memiliki rerata total kadar gula tertinggi $(6,83 \%)$. Sehingga semakin tinggi total kadar gula pada minuman sari rumput gandum semakin tinggi nilai tingkat kesukaan panelis. Adapun hubungan korelasi antara hasil uji organoleptik rasa dengan analisis total kadar gula dapat dilihat pada Gambar 4.5.

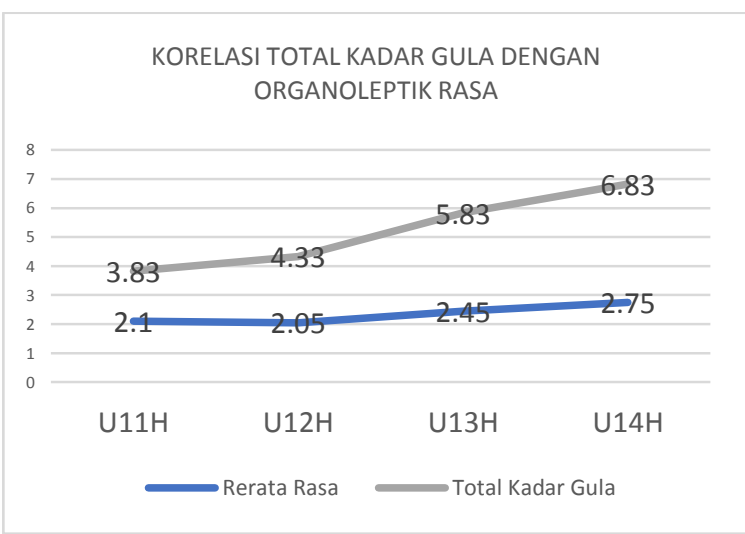

Gambar 5 Korelasi Total Kadar Gula dengan Organoleptik Rasa 
rerata warna pada perlakukan $\mathrm{U} 14 \mathrm{H}$ lebih

\section{Aroma}

Warna merupakan salah satu parameter fisik suatu bahan pangan yang penting. Kesukaan konsumen terhadap produk pangan dapat juga ditentukan oleh warna pangan tersebut (Rahayu, 2001). Uji organoleptik warna pada pembuatan minuman sari rumput gandum (wheatgrass) dilakukan untuk menilai tingkat kesukaan panelis terhadap warna produk. Warna memiliki peranan penting dalam memberikan daya tarik konsumen terhadap produk. Adapun hasil uji organoleptik rasa disajikan pada gambar 6.

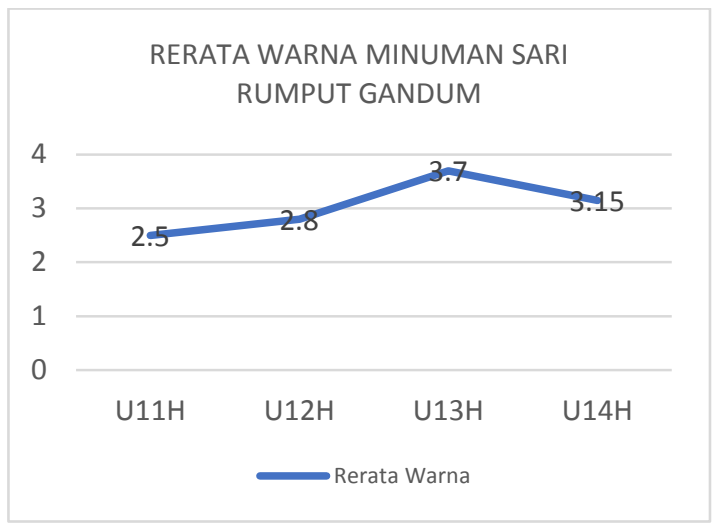

Gambar 6 Diagram Rerata Warna Minuman Sari Rumput Gandum

Pada diagram Gambar 6. di atas menunjukkan bahwa semakin lama umur panen pada pembuatan minuman sari rumput gandum (wheatgrass), semakin tinggi nilai tingkat kesukaan panelis. Hanya terdapat sedikit perbedaan pada perlakuan U13H dan U14H. Dimana nilai rendah 0,55 dengan $\mathrm{U} 13 \mathrm{H}$.

Berdasarkan hasil uji friedman terdapat beda nyata antar perlakukan pada rerata nilai tingkat kesukaan warna dengan X2 Tabel ${ }_{(0.05)}$ lebih kecil dari X2 hasil hitung $(12,435)$. Rerata nilai tertinggi didapat pada perlakuan $\mathrm{U} 13 \mathrm{H}$ (umur panen 13 hari) dengan nilai 3,70 (Sangat Suka) dan rerata nilai terendah didapat pada perlakuan U11H (umur panen 11 hari) dengan nilai 2,50 (Tidak Suka).

\section{Warna}

Uji organoleptik aroma adalah pengujian sebuah produk dengan melibatkan salah satu panca indera yaitu hidung atau biasa disebut indera penciuman. Aroma merupakan salah satu faktor yang mempengaruhi penerimaan seseorang terhadap pangan.

Aroma merupakan sifat sensori yang paling sulit untuk diklasifikasikan dan dijelaskan karena ragamnya begitu besar, karena terdapat banyak sekali jenis bebauan yang dapat dikenali oleh panca indera penciuman yaitu sekitar 17.000 senyawa volatil, dengan tingkat kepekaan yang lebih tinggi dibanding indera perasa. (Setyaningsih dkk., 2010). Hasil uji 
organoleptik aroma disajikan dalam diagram gambar 4.7 .

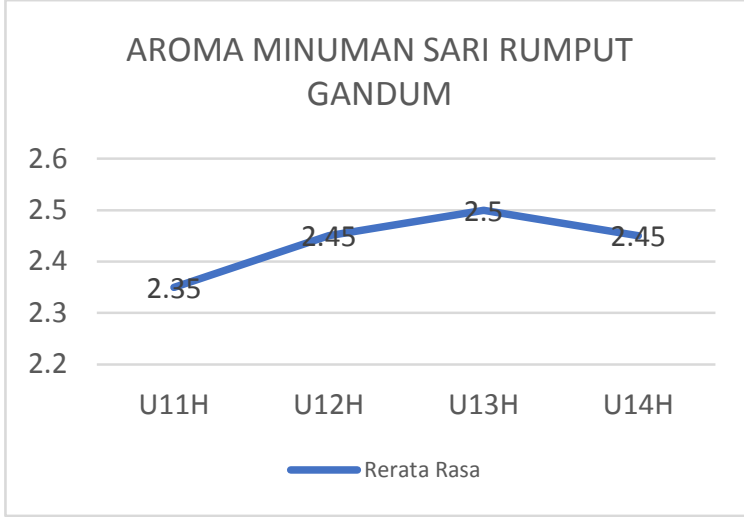

Gambar 7 Diagram Rerata Aroma Minuman Sari Rumput Gandum

Pada diagram gambar 4.7. di atas menunjukkan bahwa semakin lama umur panen, nilai kesukaan panelis terhadap aroma minuman sari rumput gandum semakin meningkat. Hanya terdapat sedikit penurunan pada perlakuan $\mathrm{U} 14 \mathrm{H}$ (umur panen 14 hari) dengan nilai perbedaan antara $\mathrm{U} 13 \mathrm{H}$ dan $\mathrm{U} 14 \mathrm{H}$ sebesar 0,05. Aroma yang timbul pada pembuatan minuman sari rumput gandum adalah aroma khas rumput. Secara umum aroma ini tidak dapat diterima oleh panelis. Berdasarkan hasil uji friedman rerata nilai yang diberikan antara 2,35 2,50 (tidak suka) dan tidak ada beda nyata antar perlakuan.

\section{Perlakuan Terbaik}

Hasil perhitungan indeks efektifitas menunjukkan kombinasi perlakuan terbaik terdapat pada $\mathrm{U} 12 \mathrm{H}$ (umur panen
12 hari) dengan total kadar gula sebesar $4,33 \%, \mathrm{pH} 6,53$, dan rendemen $82,10 \%$.

\section{KESIMPULAN DAN SARAN}

\section{Kesimpulan}

1. Tedapat pengaruh dan ada beda nyata pada umur panen terhadap total kadar gula pada minuman sari rumput gandum (wheatgrass) dengan kadar 3,83-6,83\%. Namun tidak ada beda nyata terhadap rendemen dan derajat keasaman $(\mathrm{pH})$

2. kombinasi perlakuan terbaik terdapat pada $\mathrm{U} 12 \mathrm{H}$ (umur panen 12 hari dari wheatgrass) dengan total kadar gula sebesar 4,33\%, pH 6,53, dan rendemen $82,10 \%$.

\section{DAFTAR PUSTAKA}

Agrawal, A., Gupta, E. and Chaturvedi, R. (2015). Determination of minerals and antioxidant activities at different levels of jointing stage in juice of wheat grass-the green wonder. Int. J. Pure App. Biosci, pp.311-316

Ashish, S., Shilpa, K., Singh, R. R., Sanjay, K., \& Rajendran, N. (2012). Wheatgrass: an alternative household nutritional food security. International Research Journal of Pharmacy, pp.246-250.

Muthmainnah. (2014). Laporan praktikum evaluasi sensoris acara iv uji skoring. Purwokerto. Fakultas 
Pertanian Universitas Jenderal Soedirman.

Rahayu, W.P. (2001). Penuntun praktikum penilaian organoleptik. Bogor. Jurusan Teknologi Pangan dan Gizi Fakultas Teknologi Pangan IPB.

Rahayu, S.P. (2016). Mengenal Varietas Unggul Baru "Gandum Guri-1, Guri-2, Guri-3, Guri-4. Artikel. http://cybex.pertanian.go.id/ materipenyuluhan/ detail/ 10549/ mengenal - varietas -unggul-barugandum-guri-1-guri-2-guri-3-guri-4 diakses tanggal 13 Juli 2017
Setyaningsih D, Apriyantono A, dan Sari MP. (2010). Analisis sensori untuk industri pangan dan agro. Bogor. IPB Press

Soekarto. (1990). Penilaian organoleptik untuk industri pangan dan hasil pertanian. Jakarta. Penerbit Bharata Karya Aksara.

Wigmore, A., (1985). The wheatgrass book. Penguin.

Winarno, F.G., 2004. Kimia pangan dan gizi. Jakarta. PT. Gramedia Pustaka Utama 